\title{
REVIEW
}

\section{HPV infections and lung cancer}

\section{K J Syrjänen}

Because of the major clinical impact of bronchial cancer worldwide, the possibility that human papillomavirus (HPV) contributes to its pathogenesis as a co-carcinogen is an intriguing one. Bronchial squamous cell carcinoma develops through well defined precursor lesions, often at the sites of squamous metaplasia. Benign squamous cell papillomas are rare but HPV DNA has been found in almost half of those studied, implicating a causal association. In invasive bronchial cancer, morphological changes seen in HPV lesions elsewhere are often seen. HPV DNA has been detected in $21.7 \%$ of the 2468 bronchial carcinomas analysed to date and the same high risk types implicated in other squamous cell cancers have been identified. Clearly, more effort should be focused on assessing the role of HPV in bronchial carcinogenesis, by analysing the synergistic effects of carcinogenic agents (cigarette smoke, radiation, asbestos, etc) and HPV in different experimental settings.

Correspondence to: Professor K Syriänen, Unità di Citoistopatologia, Laboratorio di

Epidemiologia e Biostatistica, Istituto Superiore di Sanità, Viale Regina Elena, 299, 1-00161 Roma, Italy; kasyrian@libero.it

Accepted for publication 25 June 2002
$\mathrm{T}$ he respiratory tract comprises several distinct anatomical sections including the nasal cavity, paranasal sinuses, nasopharynx, oropharynx, hypopharynx, larynx, trachea, and bronchi. In the major part of the respiratory tract, the epithelial lining is composed of respiratory epithelium (columnar cells), whereas stratified squamous epithelium covers the mucosa of the pharynx and larynx. ${ }^{1}$ As a result of this divergent histology of the mucosal lining, a wide variety of both benign and malignant tumours arises in the respiratory tract. ${ }^{2-6}$ This coexistence of two different epithelia also results in the presence of squamo-columnar junctions (SCJs) at multiple locations in the respiratory tract, which are considered to be a prerequisite for the spread of human papillomavirus (HPV) infections in this region, as discussed below. ${ }^{1-9}$

Of the benign tumours in this region, squamous cell papillomas (SCPs) have a well established HPV aetiology. ${ }^{13-9}$ The evidence linking HPV to the other benign and malignant tumours of the upper respiratory tract has been discussed elsewhere. ${ }^{169}$ The larynx continues with no clear anatomical hallmark down to the trachea, which is lined by a typical respiratory epithelium. These columnar cells are not the primary targets of HPV, which have their preferred sites of entry into the metaplastic squamous cells at any locus where SCJs (either natural or iatrogenic) are formed. ' Interestingly, however, HPV type 18 (HPV-18) E6 and E7 seem to be capable of immortalising primary tracheal epithelial cells. ${ }^{10}$ Indeed, such SCJs are readily detectable at various locations in the upper respiratory tract and in bronchial spurs, ${ }^{2378}$ explaining the frequently widespread dissemination of multiple laryngeal papillomatosis down to the trachea and bronchi. ${ }^{11}{ }^{12}$ This multiple papillomatosis and the not uncommon occurrence of malignant transition into squamous cell carcinoma (SCC) of the trachea and bronchi ${ }^{13-15}$ are currently thought to be manifestations of the recurrent respiratory papillomatosis (RRP) syndrome. ${ }^{1-36-8}$ This syndrome is outside the scope of this review, which is focused on the evidence linking HPV to primary bronchial tumours only.

\section{BRONCHIAL EPITHELIUM}

As in the trachea, natural and iatrogenic SCJs are the preferred site of entry for HPV in the bronchi. Undoubtedly, the most important iatrogenic cause of SCJs between the respiratory columnar epithelium and squamous epithelium in the bronchi is cigarette smoking, which frequently triggers the development of squamous metaplasia. Metaplastic squamous cells are readily detectable in sputum cytology, with or without associated dyskaryotic changes, depending on whether dysplasia is present or not. Obviously, several biochemical and metabolic aberrations occur during the metaplastic process, as shown by the dramatic changes in cytokeratin staining patterns of these metaplastic cells. ${ }^{16}{ }^{17} \mathrm{It}$ is these changes that make the metaplastic cells gradually more like squamous cells and susceptible to HPV. This is clearly shown by the recent experiments where bronchial epithelial cells were immortalised by the HPV-16 E6 and E7 oncogenes, which resulted in cells with terminally differentiated keratinocytes that were not tumorigenic in nude mice. ${ }^{18-20}$ Thus, the situation in the bronchi with multiple foci of metaplastic squamous epithelium is reminiscent of that in the transformation zone of the uterine cervix, which is the known site of entry for HPV, and also the seat for benign condylomas and cervical cancer precursor lesions. ${ }^{91}{ }^{22}$ Indeed, benign, premalignant, and malignant squamous cell lesions also occur in the bronchi, although benign lesions have received much less attention than the malignant ones.

Abbreviations: DCC, deleted in colon carcinoma; HPV, human papillomavirus; IHC, immunohistochemistry; ISH, in situ hybridisation; PCR, polymerase chain reaction; RRP recurrent respiratory papillomatosis; SSC, squamous cell carcinoma; SSCP, single stranded conformational polymorphism; SCJ, squamo-columnar junction; SCP, squamous cell papilloma 


\section{BRONCHIAL SQUAMOUS CELL PAPILLOMAS}

In addition to the multiple papillomatosis seen as a complication of RRP, solitary SCPs also exist in the bronchi. As in the trachea, this entity has been regarded as an extreme rarity. ${ }^{23}{ }^{24}$ The reported cases were reviewed in 1985 by Maxwell et al, who could collect only 11 such cases in the literature and added one of their own. ${ }^{25}$ However, this is a clear underestimate because I have identified many more cases. ${ }^{126-28}$ In Japan alone, a series of 16 such lesions was recently described. ${ }^{29}$ It should be pointed out that not all papillary tumours of the bronchus are of the squamous cell type, but can be of the inflammatory type or composed of columnar epithelium. ${ }^{25} 29$

\section{Clinical features}

Because of the rarity of these lesions, little is known about the epidemiology and clinical behaviour of solitary bronchial SCPs. ${ }^{16}$ The best account on these issues is the recent one by Flieder et al, who made a detailed analysis of the clinical and pathological features of 13 endobronchial papillomas and a single endobronchiolar papilloma, including in situ hybridisation (ISH) analysis of seven of the cases. ${ }^{30}$ The authors also identified 27 well documented cases in the literature, and used ISH to analyse HPV in four of these. Of the 41 patients, 31 were men. The age of the patients ranged from 26 to 74 years (median, 57). Three morphologically distinct histological types were recognised, namely: 27 SCPs, seven glandular papillomas, and seven mixed squamous and glandular papillomas. The authors concluded that SCPs and mixed papillomas are predominantly lesions of male smokers in their 6th decade. HPV appears to play a pathogenetic role in many SCPs, but not in mixed and glandular papillomas. Cytological atypia was present in many cases, but because of the rarity of these tumours and the difficulty in separating papillomas from endobronchial papillary SCCs, the authors did not make generalisations regarding the risk of progression to carcinoma. ${ }^{30}$

\section{Evidence for HPV involvement}

\section{Morphological evidence}

Interestingly, the first clues to the possible involvement of HPV in these benign bronchial lesions are found in two early reports from the 1970s, ${ }^{27}{ }^{28}$ the first one even before the cornerstone papers of the 1976/1977, which described the link between HPV and CIN (for review see Syrjänen and Syrjänen, ${ }^{9}$ the IARC monograph, ${ }^{21}$ and Bosch and colleagues ${ }^{22}$ ). Indeed, in the reports of Roglic et al (1975), and Rubel et al (1979), characteristic cytopathological changes of HPV (that is, koilocytosis) are found in the sputum samples derived from benign SCPs, emphasising their morphological similarity to genital condylomas. ${ }^{21}{ }^{22}$ However, it was not until 1979 that I first suggested the possible involvement of HPV in bronchial squamous cell lesions. ${ }^{31} 32$

\section{"The most important iatrogenic cause of squamo- columnar junctions between the respiratory columnar epithelium and squamous epithelium in the bronchi is cigarette smoking, which frequently triggers the development of squamous metaplasia"}

Morphologically, SCPs are like benign papillomas at other mucosal sites. ${ }^{1611}$ Not infrequently, they bear a close resemblance to exophytic condylomas of the genital tract, sometimes to the extent that warrants them being called condylomatous papillomas. ${ }^{33}$ Indeed, these authors described two primary bronchial SCPs, and emphasised their similarity to exophytic HPV lesions, which was confirmed by the demonstration of HPV antigens by immunohistochemistry (IHC) and the identification of viral particles by electron microscopy. ${ }^{33}$ Previously, such similarities had been found in bronchial SCCs. ${ }^{31}{ }^{32}$ In their recent series of SCPs, Flieder and colleagues described cytological atypia in seven of 24 lesions and a cytopathic effect of HPV in five of 24 lesions. ${ }^{30}$ Five of seven cases examined by ISH were HPV DNA positive.

\section{HPV DNA detection}

Since the awakened interest in bronchial squamous cell tumours as a potential group of HPV associated neoplasms, ${ }^{31}{ }^{32}$ several studies have searched for HPV DNA in solitary SCPs of the bronchus, using different hybridisation techniques and the polymerase chain reaction (PCR). Table l summarises these studies.

By the time we finished the chapter on HPV infections in the respiratory tract in our textbook Papillomavirus infections in human pathology, ${ }^{1}$ SCPs had been separately assessed in six studies, comprising a total of 45 cases analysed by means of ISH and/or PCR. ${ }^{38} 39434549$ HPV DNA was detected in 22 of 45 of these papillomas. Not unexpectedly, the predominant viral types are HPV-6 and HPV-11, with HPV-16 found in one lesion and HPV-18 DNA in two. Since 1998, three additional studies on HPV detection in bronchial SCPs have been published (table 1)..$^{3076} 78$ These studies contribute an additional 16 cases, of which seven were HPV DNA positive. Altogether, 61 bronchial SCPs have been analysed for HPV DNA, which was found in 29 of the lesions.

\section{Conclusions}

Thus, solitary SCPs in the bronchus do seem to resemble their morphological counterparts in other regions of the respiratory tract. Because of the small number of cases reported and the limited experience gained from these lesions, no well documented data are available on their biological behaviour. Malignant transformation of solitary bronchial SCP has not been demonstrated. As determined from their morphology and association with the low risk HPV types 6 and 11, solitary SCP of the bronchus must be considered as a benign disease. This is not unexpected in the light of the known behaviour of HPV in other anatomical regions, such as the genital tract, where HPV-6/1 1 associated exophytic condylomas are invariably benign. When assessing the evidence on the involvement of HPV in the bronchus, more important than demonstrating malignant transformation of solitary bronchial SCP is this analogy with known HPV lesions elsewhere, namely: HPV$6 / 11$ is present in benign lesions, whereas oncogenic types are detected in malignant lesions. ${ }^{91}{ }^{22}$ Undoubtedly, further studies of this entity are needed urgently.

\section{BRONCHIAL SQUAMOUS CELL CARCINOMA}

Bronchial cancer is the second most prevalent malignant tumour among both men and women. The major risk factor for lung cancer is smoking, which accounts for $75-80 \%$ of lung cancer related deaths. The incidence of lung cancer largely mirrors smoking prevalence, with a latency period of several decades. Other important risk factors for the development of lung cancer include environmental exposure to tobacco smoke, radon, occupational carcinogens, and pre-existing non-malignant lung disease. ${ }^{85-89}$ Because of its tremendous impact as a major global health problem, bronchial cancer has been the subject of intense study for many decades. The presentation of the different aspects of this research clearly falls outside the scope of this review. However, it is equally well known that not all smokers will develop bronchial cancer in their lifetime and that, in addition, these tumours do occur in patients who have never smoked. Thus, factors other than smoking may also have an impact as risk factors for lung cancer, including genetic susceptibility. ${ }^{88} 90$

Recently, more attention has been focused on these other risk factors. Thus, there seems to be a significantly increased risk for lung cancer among women who develop an anogenital malignancy. ${ }^{91}{ }^{92}$ In view of the current understanding on the important role of HPV in the development of anogenital 
Table 1 Detection of HPV DNA in bronchial papillomas and carcinomas

\begin{tabular}{|c|c|c|c|c|c|c|c|c|c|c|c|}
\hline & & & & e detect & & & & & & & \\
\hline $\begin{array}{l}\text { ypee of } \\
\text { lesion }\end{array}$ & Technique & $\begin{array}{l}\text { No. of } \\
\text { cases }\end{array}$ & 6 & $6 / 11$ & 11 & 16 & $16 / 18$ & 18 & Other & $\begin{array}{l}-l^{-10 t a l}(\%) \\
\mathrm{HPV}+\end{array}$ & First author (year) \\
\hline SQC & SB & 9 & & & & & & & & 0 & Stremlau $(1985)^{34}$ \\
\hline LCC & SB & 7 & & & & & & & & 0 & \\
\hline ASC & SB & 2 & & & & & & & & 0 & \\
\hline ASC & SB & 5 & & & & 1 & & & & 20 & \\
\hline SQC & SB & 1 & & 1 & & & & & & 100 & Byrne $(1987)^{35}$ \\
\hline SQC & ISH & 99 & & & & & 5 & & & 5 & Syriänen $(1987)^{36}$ \\
\hline SCP & EM & 1 & & & & & & & & 100 & Trillo $(1988)^{33}$ \\
\hline SQC & ISH & 131 & 2 & & & 7 & & & & 7 & Syriänen $(1989)^{37}$ \\
\hline SCP & ISH & 1 & 2 & 1 & & & & & & 100 & Kerley $(1989)^{38}$ \\
\hline SCP & ISH & 15 & & & & 1 & & & & 7 & Carey $(1990)^{39}$ \\
\hline SQM & ISH & 10 & 1 & & & & & & & 10 & Bejui-Thivol $(1990)^{40}$ \\
\hline$S Q C$ & ISH & 33 & 1 & 1 & 1 & & & 3 & & 18 & \\
\hline$S Q C$ & ISH & 1 & & 1 & & & & & & 100 & Bejui-Thivol $(1990)^{41}$ \\
\hline SQC & FISH & 5 & & & & & 2 & & & 40 & Kulski $(1990)^{42}$ \\
\hline SCP & ISH & 6 & & 6 & & & & & & 100 & Popper $(1992)^{43}$ \\
\hline$S Q C$ & ISH & 5 & & & & & $5^{*} \dagger$ & & 100 & & \\
\hline$S Q C$ & ISH & 1 & 1 & & & & & & & 100 & Dilorenzo $(1992)^{44}$ \\
\hline SQM & ISH & 17 & & 1 & & & 1 & & & 12 & Yousem $(1992)^{45}$ \\
\hline$S Q C$ & ISH & 20 & & 1 & & & 2 & & & 15 & \\
\hline ASC & ISH & 12 & & & & & & & & 0 & \\
\hline ASSC & ISH & 16 & & & & & & & & 0 & \\
\hline SQC & ISH & 4 & & & & & & & & 0 & \\
\hline ICC & ISH & 6 & & 1 & & & & & & 17 & \\
\hline SCP & ISH & 2 & & 2 & & & & & & 100 & \\
\hline SQC & $\begin{array}{l}P C R, S B \\
P B\end{array}$ & 29 & & & & 3 & & 0 & & 10 & Ogura $(1993)^{46}$ \\
\hline SCP & ISH & 1 & & 1 & & & & & & 100 & Katial $(1994)^{47}$ \\
\hline SQC & PCR, ISH & 49 & & 1 & 5 & 1 & & & & 14.2 & Liu $(1994)^{48}$ \\
\hline SCP & PCR & 20 & 3 & & 6 & 1 & & 2 & & 55 & Popper $(1994)^{49}$ \\
\hline$S Q C$ & PCR & 11 & 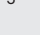 & & 0 & & & 1 & & 9 & Topper $(17744)$ \\
\hline SQC, AdC & PCR & 85 & & & & & & & & 0 & Shamanin $(1994)^{50}$ \\
\hline ISSC & PCR & 7 & & & & & & & & 0 & Szabo $(1994)^{51}$ \\
\hline SQC & PCR & 40 & & & & & & & & 0 & \\
\hline SQC & PCR, ISH & 49 & & 4 & & 2 & 2 & & & 16.3 & Xing $(1994)^{52}$ \\
\hline SQC & PCR & 66 & & 4 & 3 & 1 & & & 2 & 9 & Al-Ghamdi $(1995)^{53}$ \\
\hline SQC & $D B, S B, P C R$ & 10 & & & & & & 1 & & 10 & Kinoshita $(1995)^{54}$ \\
\hline $\mathrm{AdC}$ & $\mathrm{DB}, \mathrm{SB}, \mathrm{PCR}$ & 26 & & & & & & 2 & & 9 & \\
\hline SQC & $\mathrm{DB}, \mathrm{PCR}$ & 50 & & & & 10 & 1 & 5 & & 32 & Li $(1995)^{55}$ \\
\hline ASSC & ISH, PCR & 22 & 2 & 3 & & 1 & & 1 & $10 \ddagger$ & 36 & Nuorva $(1995)^{56}$ \\
\hline SQC & DB. PCR & 27 & & & & 7 & 1 & 5 & & 48 & Qingquan $(1995)^{57}$ \\
\hline AdC & $D B, P C R$ & 16 & & & & 2 & 0 & 0 & & 12 & \\
\hline SQC & $\mathrm{DB}, \mathrm{PCR}$ & 2 & & & & 1 & 0 & 0 & & 50 & \\
\hline ASC & $\mathrm{DB}, \mathrm{PCR}$ & 5 & & & & & & & & 0 & \\
\hline scc & $\begin{array}{ll}P C R \\
\text { PCR }\end{array}$ & 8 & & & & & & 1 & & 12.5 & Sagawa $(1995)^{58}$ \\
\hline SQC & PCR & 18 & & 1 & & 1 & & 1 & & 11 & Thomas $(1995)^{59}$ \\
\hline SQC & PCR & 34 & & & & & & & & 12 & Zhang $(1995)^{60}$ \\
\hline SQC & PCR & 9 & & & & 9 & & & & 100 & $\operatorname{Da}(1996)^{61}$ \\
\hline SQC & PCR & 16 & & & & 8 & & & & 50 & \\
\hline AdC & PCR & 12 & & & & 5 & & & & 42 & \\
\hline AdC & PCR & 4 & & 1 & & & & 1 & & 50 & Thomas $(1996)^{62}$ \\
\hline ICC & PCR & 2 & & & & & & & & 0 & \\
\hline SQC & PCR & 7 & & 2 & & & & & & 28 & \\
\hline SQC & $P C R, I S H$ & 73 & & 11 & & & 26 & 4 & & 56 & Hirayasu $(1996)^{63}$ \\
\hline AdC & $\mathrm{PCR}$ & 41 & & & & 2 & 20 & 6 & & 20 & Noutsou $(1996)^{64}$ \\
\hline SQC & PCR & 41 & & & & 2 & & 2 & & 10 & \\
\hline ICC & PCR & 10 & & & 3 & & & & $2 \ddagger$ & 20 & \\
\hline SQC & PCR & 7 & & & & & & & & 0 & \\
\hline SQC & ISH, PCR & 28 & 5 & 4 & & 6 & & 4 & $1 \neq$ & 67 & Soini $(1996)^{65}$ \\
\hline AdC & ISH, PCR & 12 & 1 & & 2 & 2 & & 3 & $5 \ddagger$ & 75 & \\
\hline SQC & ISH, PCR & 3 & & & & & & & & 0 & \\
\hline SQC & & ND & ND & & ND & ND & & & & 79 & Nakazato $(1997)^{66}$ \\
\hline SQC & ISH, PCR & 32 & & & & & & & & 0 & Welt $(1997)^{67}$ \\
\hline SQC & ISH, PCR & 6 & & & & & & & & 0 & \\
\hline SQC & $\begin{array}{l}\text { ISH, } \mathrm{PCK} \\
\text { ISH, }\end{array}$ & 34 & & & & & & 2 & & 6 & Bohlmeyer $(1998)^{68}$ \\
\hline SCP & ISH, PCR & 14 & & & & & $5 \S$ & & & 36 & Flieder $(1998)^{30}$ \\
\hline $\mathrm{scc}$ & $P C R, S B$ & 52 & & 6 & & & 11 & & ND & 69 & Papadopoulou (1998) \\
\hline ASC & ISH, PCR & 23 & & & & & 18 & & ND & 78 & Tsuhako $(1998)^{70}$ \\
\hline $\mathrm{scc}$ & PCR & 35 & & & & & & & & 0 & Wistuba $(1998)^{71}$ \\
\hline SQC & PCR, ISH & 31 & & & & & & & & 0 & Gorgoulis (1999) \\
\hline AdC & PCR, ISH & 32 & & & & & & & & 0 & \\
\hline ICC & PCR, ISH & 5 & & & & & & & & 0 & \\
\hline SQC & $P C R$ & 1 & & & & & 1 & & & 100 & Hennig $(1999)^{73}$ \\
\hline SQC & ISH, PCR & 75 & 12 & & $1+t$ & $18(5)^{* *}$ & 1 & & & 49 & Hennig $(1999)^{74}$ \\
\hline AdC & PCR, EM & 285 & & & & & 1 & ND & & 0.4 & Hiroshima (1999) 75 \\
\hline SCP & PCR & 1 & & & 1 & & & & & 100 & Kawaguchi (1999976 \\
\hline SQC & $\mathrm{HCII}$ & 185 & & & & & $5 \pi$ & & & 2.7 & Clavel (2000) $)^{77}$ \\
\hline SCP & ISH, PCR & 1 & 1 & & & 1 & & & & 100 & Harada $(2000)^{78}$ \\
\hline SQC & ISH, PCR & 44 & & & & & ND & & & 57 & Iwamasa $(2000)^{79}$ \\
\hline$S Q C$ & ISH, PCR & 157 & 9 & & 16 & 22 & & 25 & $5 \neq \ddagger$ & 49 & Miyagi $(2000)^{80}$ \\
\hline SQC & ISH, PCR & 141 & & & & & 77 & & & 55 & Cheng $(2001)^{81}$ \\
\hline$S Q C$ & $\mathrm{ISH}$ & 26 & & 1 & & & 2 & & & 11.5 & Kaya $(2001)^{82}$ \\
\hline SQC & ISH & 22 & & & & & 1 & & & 4.5 & Miasko $(2001)^{83}$ \\
\hline AdC & ISH & 13 & & 1 & & & & & & 7.6 & \\
\hline ICC & ISH & 5 & & & & & 1 & & & 20 & \\
\hline SQC & ISH, PCR & 59 & & & & & 29ND & & & 49 & Miyagi $(2001)^{84}$ \\
\hline AdC & ISH, PCR & 62 & & & & & $12 \mathrm{ND}$ & & & 19.4 & \\
\hline
\end{tabular}

*Three additional cases with HPV-31/33/35; ttwo additional cases with HPV-31/33/35; †HPV-31 and HPV-33; §ISH for HPV-6/11, HPV-16/18, and $\mathrm{HPV}-31 / 33 / 51$; Ioncogenic types in HCll assay; ${ }^{*} \mathrm{HPV}-6 / 16$; ††HPV-11/16; $\ddagger \ddagger$ triple infections.

$\mathrm{AdC}$, adenocarcinoma; AnSCC, anaplastic carcinoma; ASC, adenosquamous carcinoma; ASSC, alveolar carcinoma; DB, dot blot hybridisation; EM, electron microscopy; FISH, filter in situ hybridisation; HCII, hybrid capture II; ISH, in situ hybridisation; LCC, large cell carcinoma; ND, not defined; PCR, polymerase chain reaction; SB, Southern blot hybridisation; SCC, small cell carcinoma; SCP, squamous cell papilloma; SQC, squamous cell carcinoma; SQM, squamous cell metaplasia. 
cancer, such an association deserves more attention in the future. Interestingly, bronchial carcinomas have also been described in children. ${ }^{50}$ Again, with the above discussion of RRP in mind, the possibility of a latent HPV infection as acocarcinogen cannot be excluded. ${ }^{16993}$ Of extreme interest in this respect are the recent observations on the increased risk of lung cancer among meat handlers, ${ }^{94-96}$ because HPV infection is particularly prevalent in meat handlers (resulting in-for example, butchers wart). ${ }^{9}$ Clearly, all these recent epidemiological observations are in agreement with the concept that HPV might be involved in bronchial carcinogenesis, ${ }^{1697}$ as I originally proposed in the late 1970s. ${ }^{31}{ }^{32}$ The evidence accumulated to date is summarised in the following.

\section{Evidence for HPV involvement}

The emergence of the data implicating HPV in bronchial carcinogenesis followed an identical pattern to that seen for several other squamous cell tumours currently classified as emerging HPV lesions-for example, those of the oral mucosa, oesophagus, sinonasal mucosa, larynx, and conjunctiva. ${ }^{16998}$

\section{Morphological evidence}

Interest was aroused by morphological descriptions of epithelial changes closely resembling those of genital warts in and around bronchial SCCs. ${ }^{31}$ This primary report of a single case was immediately followed by a series of these carcinomas, which were subjected to similar analysis. ${ }^{32}$ Thus, in a series of 104 bronchial SCCs, morphologically HPV suggestive changes were identified in 36 cases: six exophytic, four inverted, and 26 flat type condylomas. This led to the hypothesis on the possible role of HPV in bronchial carcinogenesis, which is still awaiting final confirmation.

\section{Immunohistochemistry}

In contrast to many other squamous cell lesions, IHC has rarely been used to detect HPV antigens in bronchial carcinomas. ${ }^{9}$ This is because during the lag period (19791985) before there was much interest in HPV and bronchial SCC, the detection of HPV antigen expression by IHC became obsolete and was replaced by hybridisation assays for the detection of HPV DNA. Thus, the only cases analysed by IHC are the two SCPs described previously. ${ }^{33}$

\section{Detection of HPV DNA}

Therefore, all the work summarised in table 1 has been done using various hybridisation techniques, namely: dot blot, filter in situ hybridisation, ISH, Southern blot, or PCR analyses. Until January 1998, a total of 24 such studies were published, almost exclusively in the English literature. ${ }^{34-37} 40-424446505153$ $54565759-67$ The number of bronchial carcinomas analysed in these studies is substantial: 1061 cases. As has been shown in other carcinomas, the detection rates of HPV DNA are subject to a wide variation, from $0 \%$ to $100 \%$. In total, 201 of 1061 (18.9\%) of the carcinomas analysed were shown to contain HPV DNA. HPV-16 seems to be the predominant HPV type, being responsible for $49.8 \%$ of the HPV positive cases. The second in frequency is HPV- 18 , accounting for $21.8 \%$ of the positive lesions. Other high risk types detected in bronchial carcinomas include HPV types 31, 33, and 35.

\section{"In total, 201 of 1061 (18.9\%) of the carcinomas analysed were shown to contain HPV DNA"}

After this analysis, I identified extra studies covering this period (1985-1997) that were included in Medline only later, and these were mostly Japanese or Chinese in origin. ${ }^{485} 5558$ These studies substantially increase the analysed cases; 156 extra cases were studied, of which $32(20.5 \%)$ were HPV DNA positive, with HPV types 16 and 18 predominating. However, not completely unexpectedly, the low risk types HPV-6 and HPV-11 were also demonstrated in these tumours (table 1 ).

Between 1998 and 2002 (after the completion of the chapter in my textbook ${ }^{1}$ ) a substantial number of studies have appeared, which are now included in table $1 .^{68-75} 77^{79-84}$ These recent studies (based mostly on PCR and/or ISH) contribute greatly to the total number of bronchial carcinomas analysed for HPV until May 2002, by adding 1251 new cases, more than doubling the previously recorded cases $(1061+156=1217)$. Some of these studies reported, at least in part, the same patients and are only counted once. ${ }^{80} 838499$ Of these newly analysed cases, $303(24.2 \%)$ were shown to contain HPV DNA. As before, the detection rates are subject to wide a variation, from $0 \%$ to $100 \%$. The appearance of so many studies in such a short time interval reflects the greatly increased interest in these lesions among HPV researchers. The current literature now contains 2468 bronchial carcinomas subjected to HPV detection using different hybridisation methods or PCR. In total, HPV DNA has been reported in $536(21.7 \%)$ of these cases (table 1).

\section{HPV involved in multistep bronchial carcinogenesis (in} vitro studies)

I have already mentioned studies in which tracheal epithelial cells were immortalised by HPV-18 E6 and E7 oncogenes. ${ }^{10}$ More recently, similar experiments were carried out with bronchial epithelial cells, which can be readily immortalised by the HPV-16 E6 and E7 oncogenes, and show terminal differentiation of keratinocytes but are non-tumorigenic in nude mice. ${ }^{18-20}$ Such cell lines show genomic instability and telomerase activity, induced by E6/E7 expression. ${ }^{100}$ This HPV-18 immortalised cell line (BEP2D) has subsequently been studied as a model of bronchial carcinogenesis induced by radiation and asbestos fibres. ${ }^{101-106}$

Accordingly, BEP2D cells treated with high linear energy transfer radon simulated $\alpha$ particles were expanded and xenotransplanted into $\mathrm{Nu} / \mathrm{Nu}$ mice. In brief, the authors established six independent cell lines from these tumours, and revealed the following as common cytogenetic changes: loss of (1) the Y chromosome, (2) one of three copies of chromosome 8 , (3) one of three copies of chromosome 14, and (4) one of two copies of chromosome 4pl6-pter and chromosome 1lp15-pter, suggesting the presence of tumour suppressor genes on chromosome $8 .^{101}{ }^{102}$ In another recent study, alterations of p53 in the same cell line (BEP2D), induced by a single low dose of either $\alpha$ particles or $1 \mathrm{GeV} /$ nucleon (56)Fe, were analysed by PCR single stranded conformation polymorphism (SSCP) and sequencing analysis in nine primary and four secondary tumour cell lines (three of which were metastatic), together with the parental BEP2D and primary human bronchial epithelial cells (NHBE). ${ }^{103}$ PCR-SSCP and sequencing analysis found band shifts and gene mutations in all four of the secondary tumours, suggesting that p53 alterations correlate with tumorigenesis in the BEP2D cell model and that mutations in the p53 gene may be indicative of metastatic potential.

Of interest are also the recent data from experiments where BEP2D cells were used in the model of asbestos induced bronchial carcinogenesis and the expression of different genes was analysed during the stepwise malignant transformation. ${ }^{104} 105$ This model provides a unique opportunity to study the cellular and molecular changes at the various stages in fibre mediated neoplastic transformation of human bronchial epithelial cells. Most recent results suggest that activation of the insulin receptor pathway and inactivation of DCC (deleted in colon cancer) and Ku70 may cooperate in the asbestos induced malignant transformation of BEP2D cells. The same authors have also used this cell line to study the mechanisms involved in bronchial carcinogenesis induced by $\alpha$ particles from radon. ${ }^{106}$ Cells exposed to $\alpha$ particles become tumorigenic after 
progressing through a series of sequential stages including altered growth pattern, resistance to serum induced terminal differentiation, agar positive growth, tumorigenicity, and metastasis, with each step being necessary for the later steps to occur. ${ }^{106}$ Several cellular differentiation and growth regulatory genes such as DCC, p2 $1(\mathrm{ClPl})$, and the gene that encodes DNA phosphokinase were frequently found to be modulated in tumorigenic BEP2D cells.

\section{CONCLUSIONS}

The possibility that HPV might contribute (as a co-carcinogen) to the development of bronchial cancer is an intriguing one, with widespread implications-for example it may have important medico-legal consequences. There are ongoing lawsuits in many countries against the tobacco industry, where the plaintiffs (smokers who developed lung cancer) are suing the companies for their products being the cause of these malignancies. Unquestionably, cigarette smoking does cause many health problems, but certainly it cannot be the only causative factor in lung cancer, emphasising the importance of the search for additional aetiological and risk factors. ${ }^{1} 69326785-8997107$

As recently pointed out, too little effort has been put into HPV research in this particular field so far. ${ }^{19}{ }^{97}$ We know that bronchial SCC develops through well defined precursor lesions (dysplasia, carcinoma in situ), not infrequently as multifocal lesions at the sites of squamous metaplasia. ${ }^{108}$ However, the problem is how to detect these precancer lesions, and more importantly, how to treat them to prevent invasive disease. Furthermore, benign SCPs do exist, but they are rare, and do not explain the frequency of SCC, even if they underwent malignant transformation in $100 \%$ of cases, of which there is no documented evidence at the moment. The detection rate of HPV DNA in these benign papillomas approaches 50\%, although only 61 cases have been analysed. This detection rate is substantially higher than in most of the other squamous cell lesions, ${ }^{9}$ implicating a causal association.

\section{"Unquestionably, cigarette smoking does cause many health problems, but certainly it cannot be the only causative factor in lung cancer"}

In invasive bronchial cancer, morphological examination frequently detects areas with changes that closely resemble those seen in HPV lesions elsewhere (that is, koilocytosis, dyskeratosis, multinucleation, and papillomatosis). ${ }^{1631323637}$ Of the 2468 carcinomas that have undergone HPV DNA analysis to date, positive results have been obtained in $21.7 \%$ (table 1). Not surprisingly, the same high risk types that are implicated in the aetiology of genital (and other) squamous cell cancer are also involved in bronchial SCC, namely: HPV types 16, 18, 31,33 , and 35 . In adenocarcinomas of the lung, the HPV detection rate is much lower, and many studies failed to demonstrate HPV DNA in these lesions (table 1).

The detection rate of $21.7 \%$ seen in bronchial SCC is not of the same order of magnitude as that seen in the well established HPV associated carcinomas of the genital tract, but these figures are similar to those seen in squamous cell malignancies of the upper aerodigestive tract. ${ }^{9}$ This uniform prevalence (around $20 \%$ ) of HPV in malignant tumours of this particular region might imply a common aetiological pathway, leaving room for agents other than HPV, as compared with genital squamous cell carcinogenesis, where HPV seems to be the single most important aetiological factor. ${ }^{921} 22$

Clearly, more effort should be focused on assessing the role of HPV in bronchial carcinogenesis. This applies both to clinical and epidemiological studies, in addition to basic research with experimentation using HPV transformed bronchial cell lines. Of special usefulness in such studies would be the organotypic raft culture model, where the synergistic effects of

\section{Take home messages}

- Bronchial squamous cell carcinoma is a major disease burden worldwide, showing alarmingly increasing trends particularly among women in many societies

- Epidemiological and experimental data suggest that cigarette smoke, radiation, and asbestos exposure are the prime aetiological agents associated with the development of this malignancy

- Evidence for the involvement of human papillomavirus (HPV) in bronchial carcinogenesis has accumulated through several distinct lines of research: (1) HPV DNA has been detected in around $50 \%$ of benign bronchial squamous cell papillomas; (2) the detection of morphological changes suggesting HPV in bronchial cancer and its precursor lesions on light microscopy; (3) the expression of HPV structural proteins by immunohistochemistry; (4) the detection of HPV DNA by different hybridisation assays and PCR; and (5) in vitro studies (transformation of bronchial epithelial cells by oncogenic HPV types)

- HPV detection rates in bronchial carcinomas are highly variable in the different studies published from several countries, ranging from $0 \%$ to $100 \%$

- The current literature contains 2468 bronchial carcinomas subjected to HPV detection and HPV DNA has been reported in $536(21.7 \%)$ of these cases.

- The incomplete experimental data accumulated so far suggest that similar mechanisms as those detected in HPV associated cervical carcinogenesis might also be involved in bronchial carcinogenesis

- An HPV-18 immortalised bronchial cell line (BEP2D) has recently been studied as a model of multistep bronchial carcinogenesis induced by radiation and asbestos fibres

- There is reason to suspect that bronchial carcinogenesis is a multistep process, which is contributed to by the known pathogenetic factors (cigarette smoke, radiation, asbestos exposure)

- The addition of HPV to the list of potential carcinogens of the bronchus deserves far more serious attention than it has obtained so far

carcinogenic substances, such as cigarette smoke, radiation, asbestos, etc, and HPV could be analysed in different settings. ${ }^{9}$ It is only with this kind of joint research effort that the current understanding of the role of HPV in bronchial carcinogenesis can be expanded.

\section{REFERENCES}

1 Syriänen K. HPV infections in the respiratory tract. In: Syriänen K, Syriänen S, eds. Papillomavirus infections in human pathology. New York: J Wiley \& Sons, 2000:355-78.

2 Kashima HK, Mounts P. Tumors of the head and neck, larynx, lung and esophagus and their possible relation to HPV. In: Syriänen K, Gissmann L, Koss LG, eds. Papillomaviruses and human disease. Heidelberg: Springer-Verlag, 1987:138-57.

3 Kashima HK, Leventhal BG, Shah KV, et al. Recurrent respiratory papillomatosis. In: Gross G, von Krogh G, eds. Human papillomavirus infections in dermatovenereology. Boca Raton: CRC Press, 1997:323-30.

4 Syriänen S. HPV-related squamous cell tumors of the airways and esophagus. Epidemiology and malignant potential. In: Gross G, von Krogh G, eds. Human papillomavirus infections in dermatovenereology. Boca Raton: CRC Press, 1997:181-99.

5 Syriänen S. HPV-related squamous cell tumors of the airways and esophagus. Clinical presentation. In: Gross G, von Krogh G, eds. Human papillomavirus infections in dermatovenereology. Boca Raton: CRC Press, 1997:313-21.

6 Syriänen KJ, Chang F, Syriänen SM. HPV infections in etiology of benign and malignant sinonasal, bronchial and oesophageal squamous cell lesions. In: Monsonego J, ed. 4th International Multidisciplinary Congress EUROGIN 2000, Paris 5-9, April, 2000. Bologna: Monduzzi Editore, 2000:169-79.

7 Mounts P, Shah KV. Respiratory papillomatosis: etiological relation to genital tract papillomaviruses. Prog Med Virol 1984;29:90-114.

8 Kashima H, Mounts P, Leventhal B, et al. Sites of predilection in recurrent respiratory papillomatosis. Ann Otol Rhinol Laryngol 1993;102:580-3

9 Syriänen K, Syriänen S. Papillomavirus infections in human pathology. New York: J Wiley \& Sons, 2000. 
10 Yankaskas JR, Haizlip JE, Conrad M, et al. Papilloma virus immortalized tracheal epithelial cells retain a well-differentiated phenotype. Am J Physiol 1993;264:C1219-30.

11 Hyams VJ, Batsakis JG, Michaels L. Tumors of the upper respiratory tract and ear. In: Atlas of tumor pathology, 2nd series, Fascicle 25 Washington DC: Armed Forces Institute of Pathology, 1986:34-82.

12 Franzmann MB, Buchwald C, Larsen P, et al. Tracheobronchial involvement of laryngeal papillomatosis at onset. J Laryngol Otol 1994; 108: 164-5.

13 Guillou L, Sahli R, Chaubert $P$, et al. Squamous cell carcinoma of the lung in a nonsmoking, nonirradiated patient with juvenile laryngotracheal papillomatosis. Evidence of human papillomavirus-1 1 DNA in both carcinoma and papillomas. Am J Surg Pathol 1991;15:891-898.

14 Simma B, Burger R, Uehlinger J, et al. Squamous-cell carcinoma arising in a non-irradiated child with recurrent respiratory papillomatosis. Eur $J$ Pediatr 1993;152:776-8.

15 Wilde E, Duggan MA, Field SK. Bronchogenic squamous cell carcinoma complicating localized recurrent respiratory papillomatosis. Chest 1994; 105:1887-8.

16 Niimi T, Imaizumi $M$, Abe T, et al. Immunohistochemical characteristics of proliferative and metaplastic lesions in bronchial mucosa. Am J Clin Pathol 1987:88:545-51.

17 Stosiek P, Kasper M, Moll R. Changes in cytokeratin expression accompany squamous metaplasia of the human respiratory epithelium. Virchows Arch A Pathol Anat Histopathol 1992;421:133-41.

18 Willey JC, Broussoud A, Sleemi A, et al. Immortalization of normal human bronchial epithelial cells by human papillomaviruses 16 or 18 . Cancer Res 1991:51:5370-7.

19 De Silva R, Whitaker NJ, Rogan EM, et al. HPV-16 E6 and E7 genes, like SV40 early region genes, are insufficient for immortalization of human mesothelial and bronchial epithelial cells. Exp Cell Res 1994:213:418-27.

20 Viallet J, Liu C, Emond J, et al. Characterization of human bronchial epithelial cells immortalized by the E6 and E7 genes of human papillomavirus type 16. Exp Cell Res 1994;212:36-41.

21 IARC. IARC Monographs on the evaluation of carcinogenic risks to humans, Vol. 64. Papillomavirusus. Lyon: IARC, 1995.

22 Bosch XF, Lorincz A, Muñoz N, et al. The causal relation between human papillomavirus and cervical cancer. J Clin Pathol 2002;55:244-65.

23 Drennan JM, Douglas AC. Solitary papilloma of a bronchus. J Clin Pathol 1965;18:401-2.

24 Jackson DA, Hatch HB. Solitary benign squamous papilloma of the bronchus. Am Rev Respir Dis 1968;97:699-705.

25 Maxwell RJ, Gibbons JR, O'Hara MD. Solitary squamous papilloma of the bronchus. Thorax 1985;40:68-71.

26 Lee CM, Lin YN. Solitary squamous papilloma of the bronchus: report of a case. J Formos Med Assoc 1990;89:63-5.

27 Roglic $M$, Jukic S, Damjanov I. Cytology of the solitary papilloma of the bronchus. Acta Cytol 1975;19:11-13.

28 Rubel L, Reynolds RE. Cytologic description of squamous cell papilloma of the respiratory tract. Acta Cytol 1979;23:227-31.

29 Miura H, Tsuchida T, Kawate N, et al. Asymptomatic solitary papilloma of the bronchus: review of occurrence in Japan. Eur Respir J 1993;6:1070-3

30 Flieder DB, Koss MN, Nicholson A, et al. Solitary pulmonary papillomas in adults: a clinicopathologic and in situ hybridization study of 14 cases combined with 27 cases in the literature. Am J Surg Pathol 1998;22:1328-42.

31 Syriänen KJ. Condylomatous changes in neoplastic bronchial epithelium. Report of a case. Respiration 1979;38:299-304.

32 Syriänen KJ. Epithelial lesions suggestive of a condylomatous origin found closely associated with invasive bronchial squamous cell carcinomas. Respiration 1980;40:150-60.

33 Trillo A, Guha A. Solitary condylomatous papilloma of the bronchus. Arch Pathol Lab Med 1988;112:731-3.

34 Stremlau A, Gissmann L, Ikenberg H, et al. Human papillomavirus type 16 related DNA in an anaplastic carcinoma of the lung. Cancer 1985:55: 1737-40.

35 Byrne JC, Tsao MS, Fraser RS, et al. Human papillomavirus-1 1 DNA in a patient with chronic laryngotracheobronchial papillomatosis and metastatic squamous-cell carcinoma of the lung. N Engl J Med 1987;317:873-8.

36 Syriänen KJ, Syrjänen SM. Human papillomavirus DNA in bronchial squamous cell carcinomas. Lancet 1987;1:168-9.

37 Syriänen K, Syriänen S, Kellokoski J, et al. Human papillomavirus (HPV) type 6 and 16 DNA sequences in bronchial squamous cell carcinomas demonstrated by in situ DNA hybridization. Lung 1989;167:33-42

38 Kerley SW, Buchon-Zalles C, Moran J, et al. Chronic cavitary respiratory papillomatosis. Arch Pathol Lab Med 1989:113:1166-9.

39 Carey FA, Salter DM, Kerr KM, et al. An investigation into the role of human papillomavirus in endobronchial papillary squamous tumours. Respir Med 1990;84:445-7.

40 Bejui-Thivolet F, Liagre N, Chignol MC, et al. Detection of human papillomavirus DNA in squamous bronchial metaplasia and squamous cell carcinomas of the lung by in situ hybridization using biotinylated probes in paraffin-embedded specimens. Hum Pathol 1990;21:111-16.

41 Bejui-Thivolet F, Chardonnet Y, Patricot LM. Human papillomavirus type 11 DNA in papillary squamous cell lung carcinoma. Virchows Arch A Pathol Anat Histopathol 1990;417:457-61.

42 Kulski JK, Demeter T, Mutavdzic S, et al. Survey of histologic specimens of human cancer for human papillomavirus types $6 / 11 / 16 / 18$ by filter in situ hybridization. Am J Clin Pathol 1990;94:566-70.
43 Popper HH, Wirnsberger G, Juttner-Smolle FM, et al. The predictive value of human papilloma virus (HPV) typing in the prognosis of bronchial squamous cell papillomas. Histopathology 1992;21:323-30.

44 DiLorenzo TP, Tamsen A, Abramson AL, et al. Human papillomavirus type 6a DNA in the lung carcinoma of a patient with recurrent laryngeal papillomatosis is characterized by a partial duplication. J Gen Virol 1992:73:423-7.

45 Yousem SA, Ohori NP, Sonmez-Alpan E. Occurrence of human papillomavirus DNA in primary lung neoplasms. Cancer 1992;69:693-7.

46 Ogura H, Watanabe S, Fukushima K, et al. Human papillomavirus DNA in squamous cell carcinomas of the respiratory and upper digestive tracts. Jpn J Clin Oncol 1993;23:221-5.

47 Katial RK, Ranlett R, Whitlock WL. Human papilloma virus associated with solitary squamous papilloma complicated by bronchiectasis and bronchial stenosis. Chest 1994;106:1887-9.

48 Liu HR, Xing LQ, Si JY. [A study of human papillary virus infection by in situ hybridization and histopathology in squamous cell carcinoma of the lung]. Chung Hua Ping Li Hsueh Tsa Chih 1994;23:299-301.

49 Popper HH, el-Shabrawi Y, Wockel W, et al. Prognostic importance of human papilloma virus typing in squamous cell papilloma of the bronchus: comparison of in situ hybridization and the polymerase chain reaction. Hum Pathol 1994;25:1191-7.

50 Shamanin V, Delius H, de-Villiers EM. Development of a broad spectrum PCR assay for papillomaviruses and its application in screening lung cancer biopsies. J Gen Virol 1994;75:1149-56.

51 Szabo I, Sepp R, Nakamoto K, et al. Human papillomavirus not found in squamous and large cell lung carcinomas by polymerase chain reaction. Cancer 1994;73:2740-4.

52 Xing LQ, Liu HR, Si JY. [Analysis of the characteristics of human papilloma virus infection in 85 neoplasms of the respiratory system in adult patients]. Zhonghua Zhong Liu Za Zhi 1994;16:424-7.

53 al-Ghamdi AA, Sanders CM, Keefe $M$, et al. Human papillomavirus DNA and TP53 mutations in lung cancers from butchers. Br J Cancer $1995 ; 72: 293-7$

54 Kinoshita I, Dosaka-Akita $H$, Shindoh $M$, et al. Human papillomavirus type 18 DNA and E6-E7 mRNA are detected in squamous cell carcinoma and adenocarcinoma of the lung. Br J Cancer 1995;71:344-9.

55 Li Q, Hu K, Pan X, et al. Detection of human papillomavirus types 16, 18 DNA related sequences in bronchogenic carcinoma by polymerase chain reaction. Chin Med J (Engl) 1995;108:610-14.

56 Nuorva K, Soini Y, Kamel D, et al. p53 protein accumulation and the presence of human papillomavirus DNA in bronchiolo-alveolar carcinoma correlate with poor prognosis. Int J Cancer 1995:64:424-9.

57 Qingquan L, Xianguang P, Zuoyan C, et al. Detection of human papillomavirus types 16, 18 DNA related sequences in bronchogenic carcinoma by polymerase chain reaction. Chin Med J (Engl) 1995; 108:610-14.

58 Sagawa $M$, Saito $Y$, Endo $C$, et al. [Detection of human papillomavirus type 16, 18 and 33 DNA in stage I (pTINOMO) squamous cell carcinoma of the lung by polymerase chain reaction]. Kyobu Geka 1995;48:360-2.

59 Thomas P, De-Lamballerie X, Garbe L, et al. Detection of human papillomavirus DNA in primary lung carcinoma by nested polymerase chain reaction. Cell Mol Biol 1995;41:1093-7.

60 Zhang $X$, Zhu Y, Li L. Point mutation of $\mathrm{p} 53$ and detection of human papillomavirus DNA in bronchogenic carcinoma. Chung Hua Nei Ko Tsa Chih 1995;34:673-5

61 Da J, Chen L, Hu Y. Human papillomavirus infection and p53 gene mutation in primary lung cancer. Chung Hua Chung Liu Tsa Chih $1996 ; 18: 27-9$

62 Thomas P, De-Lamballerie X, Garbe L, et al. Detection of human papillomavirus by polymerase chain reaction in primary lung carcinoma. Bull Cancer 1996:83:842-6.

63 Hirayasu T, Iwamasa T, Kamada Y, et al. Human papillomavirus DNA in squamous cell carcinoma of the lung. J Clin Pathol 1996;49:810-17.

64 Noutsou A, Koffa M, Ergazaki M, et al. Detection of human papilloma virus (HPV) and K-ras mutations in human lung carcinomas. Int J Oncol 1996;8:1089-93

65 Soini Y, Nuorva K, Kamel D, et al. Presence of human papillomavirus DNA and abnormal p53 protein accumulation in lung carcinoma. Thorax 1996;51:887-93.

66 Nakazato I, Hirayasu T, Kamada Y, et al. Carcinoma of the lung in Okinawa, Japan: with special reference to squamous cell carcinoma and squamous metaplasia. Pathol Int 1997:47:659-72.

67 Welt A, Hummel M, Niedobitek $G$, et al. Human papillomavirus infection is not associated with bronchial carcinoma: evaluation by in situ hybridization and the polymerase chain reaction. J Pathol 1997; 181:276-80

68 Bohlmeyer T, Le TN, Shroyer AL, et al. Detection of human papillomavirus in squamous cell carcinomas of the lung by polymerase chain reaction. Am J Respir Cell Mol Biol 1998;18:265-9.

69 Papadopoulou K, Labropoulou V, Davaris P, et al. Detection of human papillomaviruses in squamous cell carcinomas of the lung. Virchows Arch 1998;433:49-54

70 Tsuhako K, Nakazato I, Hirayasu T, et al. Human papillomavirus DNA in adenosquamous carcinoma of the lung. J Clin Pathol 1998;51:741-9.

71 Wistuba II, Behrens C, Milchgrub S, et al. Comparison of molecular changes in lung cancers in HIV-positive and HIV-indeterminate subjects. JAMA 1998;279:1554-9.

72 Gorgoulis VG, Zacharatos P, Kotsinas A, et al. Human papilloma virus (HPV) is possibly involved in laryngeal but not in lung carcinogenesis. Hum Pathol 1999;30:274-83. 
73 Hennig EM, Di Lonardo A, Venuti A, et al. HPV 16 in multiple neoplastic lesions in women with CIN III. J Exp Clin Cancer Res 1999;18:369-77.

74 Hennig EM, Suo Z, Karlsen F, et al. HPV positive bronchopulmonary carcinomas in women with previous high-grade cervical intraepithelia neoplasia (CIN III). Acta Oncol 1999;38:639-47.

75 Hiroshima K, Toyozaki T, lyoda A, et al. Ultrastructural study of intranuclear inclusion bodies of pulmonary adenocarcinoma. Ultrastruct Pathol 1999;23:383-9

76 Kawaguchi T, Matumura A, luchi K, et al. Solitary squamous papilloma of the bronchus associated with human papilloma virus type 11. Intern Med 1999:38:817-19.

77 Clavel CE, Nawrocki B, Bosseaux B, et al. Detection of human papillomavirus DNA in bronchopulmonary carcinomas by hybrid capture II: a study of 185 tumors. Cancer 2000;88:1347-52.

78 Harada H, Miura K, Tsutsui Y, et al. Solitary squamous cell papilloma of the lung in a 40-year-old woman with recurrent laryngeal papillomatosis. Pathol Int 2000;50:431-9.

79 Iwamasa T, Miyagi J, Tsuhako K, et al. Prognostic implication of human papillomavirus infection in squamous cell carcinoma of the lung. Pathol Res Pract 2000;196:209-18.

80 Miyagi J, Tsuhako K, Kinjo T, et al. Recent striking changes in histological differentiation and rate of human papillomavirus infection in squamous cell carcinoma of the lung in Okinawa, a subtropical island in southern Japan. J Clin Pathol 2000;53:676-84

81 Cheng YW, Chiou HL, Sheu GT, et al. The association of human papillomavirus 16/18 infection with lung cancer among nonsmoking Taiwanese women. Cancer Res 2001;61:2799-803.

82 Kaya $\mathbf{H}$, Kotiloglu E, Inanli S, et al. Prevalence of human papillomavirus (HPV) DNA in larynx and lung carcinomas. Pathologica 2001;93:531-4.

83 Miasko A, Niklinska W, Niklinski J, et al. Detection of human papillomavirus in non-small cell lung carcinoma by polymerase chain reaction. Folia Histochem Cytobiol 2001;39:127-8.

84 Miyagi J, Kinjo T, Tsuhako K, et al. Extremely high Langerhans cell infiltration contributes to the favourable prognosis of HPV-infected squamous cell carcinoma and adenocarcinoma of the lung. Histopathology 2001;38:355-67

85 Benhamou S, Benhamou E, Flamant R. Lung cancer risk associated with cigar and pipe smoking. Int J Cancer 1986;37:825-9

86 Franco EL. Multiple cancers of the upper aero-digestive tract: the challenge of risk factor identification. Cancer Lett 1991;60:1-8.

87 Cersosimo RJ. Lung cancer: a review. Am J Health Syst Pharm 2002;59:61 1-42

88 Moore TO, Moore AY, Carrasco D, et al. Human papillomavirus, smoking, and cancer. J Cutan Med Surg 2001;5:323-8.

89 Bilello KS, Murin S, Matthay RA. Epidemiology, etiology, and prevention of lung cancer. Clin Chest Med 2002;23:1-25.

90 Nakachi K, Imai K, Hayashi S, et al. Genetic susceptibility to squamous cell carcinoma of the lung in relation to cigarette smoking dose. Cancer Res 1991;51:5177-80.
91 Rabkin CS, Biggar RJ, Melbye M, et al. Second primary cancers following anal and cervical carcinoma: evidence of shared etiologic factors. Am J Epidemiol 1992;136:54-8.

92 Frisch M, Melbye M. Risk of lung cancer in pre- and post-menopausal women with ano-genital malignancies. Int J Cancer 1995;62:508-1 1.

93 Keita O, Lagrange J-L, Michiels J-F, et al. Primary bronchogenic squamous cell carcinoma in children: report of a case and review of the literature. Med Pediatr Oncol 1995;24:50-2.

94 Coggon D, Pannett B, Pippard EC, et al. Lung cancer in the meat industry. BrJ Ind Med 1989;46:188-91.

95 Kristensen TS, Lynge E. Lung cancer among butchers and slaughterhouse workers. Scand J Work Environ Health 1993; 19:137-47.

96 Benton EC. Warts in butchers-a cause for concern? Lancet 1994;343: 1114

97 Markham AF. Carcinoma of the lung: warts and all. Thorax 1996:51:878-9.

98 Syriänen K. HPV infections and oesophageal cancer [review]. J Clin Pathol 2002;55:721-8.

99 Miasko A, Chyczewska E, Niklinska W, et al. [The role of human papilloma viruses (HPV) in the pathogenesis of lung neoplasms]. Pneumonol Alergol Pol 2000;68:379-87.

100 Coursen JD, Bennett WP, Gollahon L, et al. Genomic instability and telomerase activity in human bronchial epithelial cells during immortalization by human papillomavirus-16 E6 and E7 genes. Exp Cell Res 1997;235:245-53

101 Weaver DA, Hei TK, Hukku B, et al. Cytogenetic and molecular genetic analysis of tumorigenic human bronchial epithelial cells induced by radon alpha particles. Carcinogenesis 1997; 18:1251-7.

102 Weaver DA, Hei TK, Hukku B, et al. Localization of tumor suppressor gene candidates by cytogenetic and short tandem repeat analyses in tumorigenic human bronchial epithelial cells. Carcinogenesis 2000;21:205-11.

103 Piao CQ, Willey JC, Hei TK. Alterations of p53 in tumorigenic human bronchial epithelial cells correlate with metastatic potential. Carcinogenesis 1999;20:1529-33.

104 Hei TK, Wu L, Piao CQ. Malignant transformation of immortalized human bronchial epithelial cells by asbestos fibers. Environ Health Perspect 1997;105(suppl 5): 1085-8.

105 Zhao YL, Piao CQ, Wu L, et al. Differentially expressed genes in asbestos-induced tumorigenic human bronchial epithelial cells: implication for mechanism. Carcinogenesis 2000;21:2005-10.

106 Zhao YL, Piao CQ, Hall EJ, et al. Mechanisms of radiation-induced neoplastic transformation of human bronchial epithelial cells. Radiat Res $2001 ; 155: 230-4$

107 Syriänen K. Papillomavirus infections and cancer. In: Syrjänen K Gissmann L, Koss LG, eds. Papillomaviruses and human disease. Heidelberg: Springer-Verlag, 1987:468-503

108 Nagamoto N, Saito Y, Sato M, et al. Clinicopathological analysis of 19 cases of isolated carcinoma in situ of the bronchus. Am J Surg Pathol 1993; 17:1234-43.

\section{$\mathrm{ECHO}$}

\section{Iron deposits may damage joint tissue in RA}

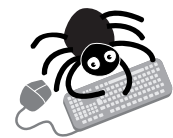

Please visit the Molecular Pathology website [www. molpath.com] for link to this full article. ur understanding of the role of iron in rheumatoid arthritis (RA) has improved with a recent study showing where iron accumulates in the synovial membranes of affected joints. The researchers speculate how iron might build up to toxic amounts.

Ferritin, both light and heavy subunits, was found in the lining layer and subintimal zone of the synovium and in synovial macrophages and fibroblasts. Transferrin receptor appeared only in the lining layer.

Non-specific resistance associated macrophage proteins (Nramp) were also found. These are proteins that span membranes and transport divalent cations. Nramp 2 occurred in macrophages and fibroblasts. Nramp 1 was present in macrophages and neutrophils, in the synovial lining layer and the subintimal zone, and in infiltrating inflammatory cells, but not in fibroblasts.

The study used synovial membranes from arthroplasties of 20 patients with RA. Thin sections were stained cytochemically for ferritin, transferrin receptor, and Nramp 1 with monoclonal or poylclonal antibodies. Macrophages and fibroblasts were isolated from collaginase digests of synovial membranes. Neutrophils were isolated from synovial fluid aspirated routinely from the joints. These cell types were stained for ferritin and transferrin receptor immunocytochemically. Nramp 1 and Nramp 2 were identified by reverse transcriptase polymerase chain reaction.

A high iron content has been noted in synovial membranes in RA, but the uptake and storage of iron and its potential relation to inflammation of the joints has been unknown until now.

A Annals of the Rheumatic Diseases 2002;61:741-744. 